\title{
READING AND WRITING POEMS IN ENGLISH: COLLABORATIVE PRACTICES AT A BRAZILIAN PUBLIC SCHOOL
}

\author{
LEITURA E ESCRITA DE POEMAS EM INGLÊS: \\ PRÁTICAS COLABORATIVAS EM UMA ESCOLA \\ PÚBLICA BRASILEIRA
}

\section{Layssa Gabriela Almeida e Silva Mello*}

\begin{abstract}
This study, presenting an experience with eighth-grade students at a Brazilian public school, in Goiânia, Goiás, shows students' ability to collaboratively read and write poems in English. A poem was selected from the Indian-born, Canadian poet Rupi Kaur's book The sun and ber flowers (KAUR, 2017) to discuss and reflect on themes such as love and loss. Firstly, a theoretical reference on the importance of literary texts for English language teaching and the role of collaboration is presented to provide a theoretical basis for this pedagogical practice. The pre-reading, while-reading and post-reading activities are then described and the students' written productions, based on Rupi Kaur's poem, are also presented. Through these activities, students enhanced their lexical knowledge of the English language and their creativity, and also interacted with their colleagues to reflect on current issues.
\end{abstract}

Keywords: reading; writing; poems.

\section{RESUMO}

Este trabalho, que apresenta a experiência com alunos do $8^{\circ}$ ano de uma escola pública brasileira, na cidade de Goiânia, Goiás, revela a habilidade dos alunos de lerem e escreverem poemas em inglês de forma colaborativa. Um poema do livro The sun and her flowers (KAUR, 2017) foi selecionado, da poetisa canadense Rupi Kaur, nascida na Índia, a fim de discutir e refletir sobre temas como amor e perda. Inicialmente é apresentado referencial teórico sobre a importância de textos literários no ensino de língua inglesa e colaboração para fundamentar nosso estudo. As atividades de pré-leitura, leitura e pós-leitura são descritas e as produções escritas dos alunos baseadas no poema da Rupi Kaur também são apresentadas. Por meio dessas atividades, os alunos foram capazes de melhorar o conhecimento lexical da língua inglesa, sua criatividade assim como de interagir com os colegas a fim de refletir sobre temas atuais.

Palavras-chave: leitura; escrita; poemas.

\footnotetext{
* Universidade Federal de Goiás, UFG, Goiânia, GO, Brasil. layssagabriela@hotmail.com

Orcid: https://orcid.org/0000-0001-6264-1290
} 


\section{INTRODUCTION}

Several tragedies occurred in Brazil at the beginning of 2019, such as the collapse of a dam in Brumadinho, a fire at the Flamengo Training Center, a helicopter crash which killed the Brazilian journalist Ricardo Boechat and a shooting at a public school in São Paulo. All these tragedies made us reflect, even if subconsciously, on the ephemerality of life. To begin the school year, I decided to discuss a poem, This is the recipe of life, by the contemporary feminist poet, Rupi Kaur, with my eighthgrade group in a public school in Goiânia, Goiás'.

Born in 1992, in Punjabi, India, Rupi Kaur emigrated to Toronto, Canada, when she was only 4 years old. She started her career as a poet on social media, via Instagram and Tumblr. In October 2015, she assembled her compositions and published her first book, Milk and boney (KAUR, 2015), translated into Brazilian Portuguese as Outros jeitos de usar a boca (KAUR, 2018a). Her second book, The sun and her flowers (KAUR, 2017), translated in Brazil as O que o sol faz com as flores (KAUR, 2018b), was divided into five parts: wilt, fall, root, grow and bloom, corresponding to the phases of the life cycle of a flower. In it she explores a variety of themes including loss, trauma, healing, femininity, migration and revolution. The poem, This is the recipe of life, selected from this book for reflection with my eighth-grade students was chosen with the intention of discussing and rethinking themes such as love and loss through collaborative practices.

This paper is organized into three parts. The first presents authors who advocate the approach of using literary texts in foreign language classrooms, while the second introduces studies which ground this paper in terms of collaboration and interaction in the language classroom. Then, the pre-reading, while-reading and post-reading activities undertaken with the students are described and the learners' written productions based on the selected poem are presented, reporting the benefits and challenges faced by the researcher teacher in the collaborative process of reading and writing poems in English at a Brazilian public school.

\section{THE IMPORTANCE OF LITERARY TEXTS IN ENGLISH LANGUAGE TEACHING}

Wanderley (2017, p. 185) states that we are facing a "scenario where the surface takes over the worldviews and distances people from empathetic acts" ${ }^{\prime \prime}$.

1. This paper was written for the Applied Linguistics: Foreign Language Teaching and Learning Course, given by Professors Neuda Alves do Lago and Francisco José Quaresma de Figueiredo in the Programa de Pós-Graduação em Letras e Linguística, at Universidade Federal de Goiás.

2. Texts translated from Portuguese are the author's free translations. 
Hence, she advocates reading practices which could help deconstruct this context and enable the individual to look at the other and at themselves in a more empathetic way. I believe that we can approach literary texts to promote such reading practices. Many experts have demonstrated the benefits of using literary texts to promote second language teaching and learning. According to Valdes (2001), literary texts can be used as a tool for discussing cultural aspects because they transmit the culture of the people presented in a particular written text.

Lago (2017), in turn, carried out research with nine senior students majoring in English at a Brazilian university, to investigate their understanding of a metaphorical text in foreign literature. The data showed that even though students faced certain obstacles while reading literary texts in another language, such as the barrier of vocabulary and a distinct structuring of the world, their collaborative work led them to a greater comprehension of English poetry.

According to Brumfit and Carter (1986), students can start inferring meaning as a result of their interaction with literary texts. Among other things, such texts are not written in a simple or conventional way, as the readers are required to be active during the reading process, and look for clues, both within and beyond the text.

In a study on the use of literary texts in English language teaching in Brazil in two different types of school setting, a public school and a language center, Rees, Pereira and Mello (2018) showed that activities based on literary texts enabled students to interact with the languacultures of the texts. These activities also contributed to transforming the English language classroom into a critical intercultural space in which learners recreated their understanding of the target language, by actively working on the construction of knowledge.

Collie and Slater $(1990$, p. 3) in Literature in the Language Classroom provide ideas, approaches and techniques which have worked in their classrooms based on the use of literary texts. Their book is organized around the following three questions: a) Why is literature profitable to the language learning process? b) What works are appropriate for use in the foreign language classrooms? and c) How can we rethink the way we present and approach literature in order to design a broader range of more engaging activities for our students?

They focus on four aspects to respond to the first question. According to them, literature is profitable because it is valuable authentic material and, provides cultural and language enrichment as well as fostering the personal involvement of the reader (COLLIE; SLATER, 1990, p. 3-5). In response to the second question, they explain that suitability is directly related to a particular group of students, because of their "needs, interests, cultural background and language level" (COLLIE; 
SLATER, 1990, p. 6). They emphasize the need to select books which are relevant to students' life experiences, emotions or dreams. For the final question, there is no simple answer. In order to rethink how literature can be presented and approached in a more engaging way for students, pair and group work should be encouraged as a means to increasing learners' confidence, and they must be helped to explore their own responses to literature (COLLIE; SLATER, 1990, p. 9). They will, thus, be more engaged in the activities as they begin to feel part of the learning process.

Despite the innumerous benefits accruing from using literary texts to teach and learn a second language, many teachers still do not include them in their practices. They claim that because literary texts are difficult to understand, it would be better not to use them in the classroom. Short and Candlin (1986, p. 91) contend that although teachers often distinguish between language and literature students, for whom "literature is also language", do not.

Thus, it is crucial to emphasize that the focus of literary texts used in a foreign language classroom, and more specifically, in a Brazilian public school, should not be on literary periods, or through difficult structural analyses. Rather, the literary texts should be used as a real sample of language, as a tool which enables learners to reflect on current topics and the languacultures in which they are written.

\section{THE ROLE OF COLLABORATION AND INTERACTION IN THE CLASSROOM}

Collaborative learning is a constructivist philosophical approach which refers to educational situations in which two or more people learn or try to learn something together and whose emphasis is on the co-construction of knowledge. It assumes that students work together to achieve common goals. Through this interaction, learners share ideas, information and learning strategies (FIGUEIREDO, 2018).

Vygotsky (1998) states that children's cognitive development occurs via interaction with more experienced children or with adults. This cognitive development can be described in terms of real and potential levels. The real level represents the activities children can do by themselves, while the potential level represents those activities which children can perform with the help of another. Vygotsky uses the term Zone of Proximal Development (ZPD) to explain the difference between what a learner can do without help and what he/she cannot do without assistance.

The scaffolding metaphor is used in language teaching to describe the assistance given to a child or learner during problem solving tasks. As stated by Figueiredo (2019, p. 48), the help given to a child or learner by an adult or more 
experienced peer can occur by means of "instruction, patterns to be followed, questions, monitoring". In other words, adults or more experienced peers can assist children or learners to reflect and act while carrying out a task. It should be noted that this help is temporary and that children or learners do not receive it passively as they are actively engaged in this interaction, and pay attention to everything so that they can benefit from it and improve their knowledge.

Although substantial benefits result from the process of getting students to work together, teachers must also consider that certain students do not feel comfortable when working in pairs or in groups. They may prefer to work alone. Thus, teachers must respect students' different learning styles and not oblige them to work in groups (FIGUEIREDO, 2018).

Many experts have analyzed the use of the collaborative approach in the English language classroom. They have discovered that in pairs, students work together and are better able to identify and correct their errors (FIGUEIREDO, 2015). They can help each other with reading comprehension (SABOTA, 2018), the development of communicative strategies (FIGUEREDO, 2018), and strategies to help with writing, such as using the student's mother tongue and dictionaries, private conversation and requests for clarification (WOBETO, 2012).

\section{RESEARCH METHODS}

This case study was undertaken with a group of thirty eighth-grade students at a Brazilian public school in Goiânia. It was a heterogeneous class of 13- and 14-year-olds, some of whom had an intermediate level of proficiency while others had a basic level. They try to speak English more frequently than in previous years and sometimes even spoke Portuguese in class, as I also did, in order to be understood. As already mentioned, a poem from The sun and her flowers (KAUR, 2017) was selected for reflection on themes such as love and death.

Four research instruments were used for data generation (MASON, 1997): a) the teacher's lesson plans describing the pre-reading, while-reading and postreading activities undertaken with the students, based on a poem $;$ b) a field journal, used by the researcher teacher to make notes on the students' involvement and participation during the process. Notes were taken in English both during and after classes, in the following manner. When notes were taken during classes, the researcher teacher wrote key words related to a student's participation and their names on the board, and immediately after the class, she wrote the complete sentences into the field journal and also availed of the moment to evaluate their 
involvement and participation in general; c) students' written production of a poem; and d) students' feelings about reading and writing a poem in English in a collaborative way, written in paragraph form at the end of the case study.

It took four 45 -minute classes to generate the data. The first class dealt with the pre-reading activity, while the second dealt with the while-reading. In the third and fourth classes, students produced their poems in pairs and later on wrote a paragraph describing their experience of the activity. The names of the participants presented in this study are fictitious so as to preserve their identity. Each step of the process is now described.

\subsection{Pre-reading activities}

I prepared a PowerPoint Presentation as a warm-up to start a discussion with students before reading the poem. First, I asked if anybody had heard of Rupi Kaur, but unfortunately, none had ever heard of her. So, I presented some facts about her life, a map of Canada showing where she lives, and the covers of two of her books. We talked about the Brazilian translations of the titles.

Students were impressed by the way the titles of her works were translated into Brazilian Portuguese and mentioned that it is quite common to find in Sessão da Tarde, a Brazilian TV program in which dubbed movies are shown, that the translated movie titles differ greatly from their originals.

After discussing Rupi Kaur's life, I showed them pictures containing vocabulary which, in my experience, they would not have known and would probably have had difficulty in understanding while reading the selected poem. This step could be considered a scaffolding strategy (FIGUEIREDO, 2019), as the pictures were presented to them and they had to discover how to say these words in English. The slides involved these words: recipe, weep (for this slide we discussed the difference between weep and cry), wilt, fall, root and rise.

A retrospective of the beginning of 2019 followed with a focus on images of tragedies which occurred in Brazil such as the collapse of a dam in Brumadinho, the fire at the Flamengo Training Center, the helicopter crash which killed the Brazilian journalist Ricardo Boechat and the shooting in a public school in São Paulo.

The students were asked to answer the following question: How did 2019 start? They used expressions such as "really bad", "evil" and "a lot of deaths", all of which were written on the blackboard. To end this pre-reading section, students also had to orally answer: Did you think about your life and those you love after seeing all these tragic happenings in Brazil? Some of the answers were: 
[1] Field Journal - Students' oral participation during the pre-reading activity

Yes, teacher, I got scared and afraid. (Maria)

Yes, because I discovered that life changes easily. (Duda)

Yes, people are getting crazy and I was afraid to come to school. (Ana)

Yes, I felt the horror. (João)

Yes, I noticed that my country is lost. (Daniel)

No, because none of these tragedies occurred in Goiânia and I didn't lose any relatives or friends. (Isa)

As some of these answers present the students' impressions on these tragedies, it is important to mention that the majority of the group felt insecure and afraid and just one student pointed out that she was not afraid because the tragedies did not directly affect her reality. As this pre-reading discussion involved the whole group and all had an opportunity to listen to and give their opinions on the topic, some of her classmates started to question Isa so as to get a better understanding of what she had said. As shown by Wobeto (2012), requesting clarification is a strategy used by students when working collaboratively. The questions they asked Isa included: "Didn't you feel sad after seeing so many deaths?" (Duda, field journal) "Didn't you see on TV that there are many dams with problem in Goiás and that a similar situation may occur here?" (Daniel, field journal). Isa emphasized that she did not feel happy with the situation and since none of her family members died, she was not sad. She also mentioned she was not aware of dam problems in Goiás.

As can be seen, the collaborative debate held at the pre-reading stage enabled students to reflect on the tragedies that occurred in Brazil at the beginning of 2019 and how these tragedies had influenced their lives in the sense of feeling scared and terrified. The debate also enabled one student to become aware of a problem involving our State, one that she had not heard about: the problematic dams in Goiás.

\subsection{While-reading}

Students were asked to divide into pairs and were given a copy of the poem: 


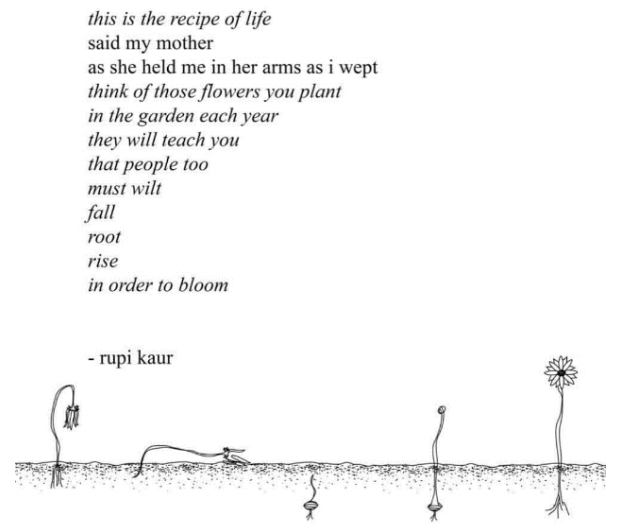

Figure 1. This is the recipe of life (KAUR, 2017, p. 105):

As can be seen, the poem is short, the vocabulary is easily understood by foreign learners of English and it comes with an illustration which helps to better interpret it. Collie and Slater (1990) stress that teachers must be aware of students' needs, interests and language level when selecting an appropriate literary text for a particular group and must help learners to explore their own responses to literature. Considering these tips, the students were given five minutes to read the poem in pairs after which they orally shared their opinions on it. I believe it was during this pair work activity that students started to infer meaning (BRUMFIT; CARTER, 1986), as a result of their interaction with the poem and with their colleagues.

They used various positive adjectives to describe Rupi Kaur's poem such as "wonderful", "amazing", "incredible", and sentences such as "This poem tells everything, it's perfect", "Oh, it touched my heart", and "It is an inspirational poem".

When asked what they could take from it they said:

[2] Field Journal - Students' opinions during the while-reading activity

Sometimes bad things can happen in our lives, but we must be strong enough to keep fighting. (Ricardo)

Bad things do not last forever. (Amanda)

Life is a cycle with bad and good moments. (João)

That we have to go through the bad moments in order to grow up. (Pedro)

In life we must fall, but we should rise and bloom, so we have the opportunity to reap what we planted. (Duda)

I have an ipê and it died two weeks ago. After reading this poem I think that I am going to take care of it, because there's a chance to bloom again. (Roberto) 
Everybody referred to the poem in a positive way, as it had something motivational for their lives. Roberto mentioned a positive point when reading the poem. As it talks about the cycle of a plant, it made him think about his own reality and culture and he realized that it was not necessary to dispose of his ipê. He could take care of it, in the hope that it would bloom again soon. The poem contributed here to transforming the English language classroom into a critical intercultural space (REES, PEREIRA; MELLO, 2018), where Roberto was able to recreate his understanding of the target language, actively working on the construction of meaning.

\subsection{Post-reading}

As a post-reading exercise, students were asked to collaboratively write a poem in pairs, illustrate them and then hand them in to the teacher. At this moment, I encouraged them to use a dictionary and told them that they could ask me if they had any questions.

Isa asked for help at this stage in the activity. She told me that she did not know how to start the activity, as poems "are tough stuff". I tried to motivate her and asked her what specific part of Rupi Kaur's poem she did not understand. She realized that, linguistically speaking, she had understood all of it. Although she understood everything, she stressed that "poems are generally difficult to be grasped, everybody says that". This idea of seeing literature as something inaccessible is also shared by Vinny, a participant in the research carried out by Lago (2016, p. 664), for whom "literature is not for the poor mortals". Coming back to Isa's case, I tried to emphasize to her, that Rupi Kaur's poem proves that not all poems are difficult to understand and that she could choose any topic she liked as a basis for her poem. And besides, she had a classmate as a partner on that journey. She smiled and consented to do the proposed activity.

After handing in their productions, the pairs had to write a paragraph on their feelings about collaboratively reading and writing a poem in English. 


\subsection{Students' production}

Because of the limitation of space in this paper, I selected the production of seven different students for presentation here, or roughly half of the production handed to me. Some of the students' productions showed that they used Rupi Kaur's poem as a guide, and availed of its structure, but they were able to use the language in a creative way and express their feelings in a written genre.

[3] Ana and Bia's production

The recipe of love

this is the recipe of love said everybody as I wept on their shoulders think of all the people you love

they will hurt you sometimes they will ignore you too but this will teach you that some things are not how we expect everything has its time you just have to wait and you will be okay

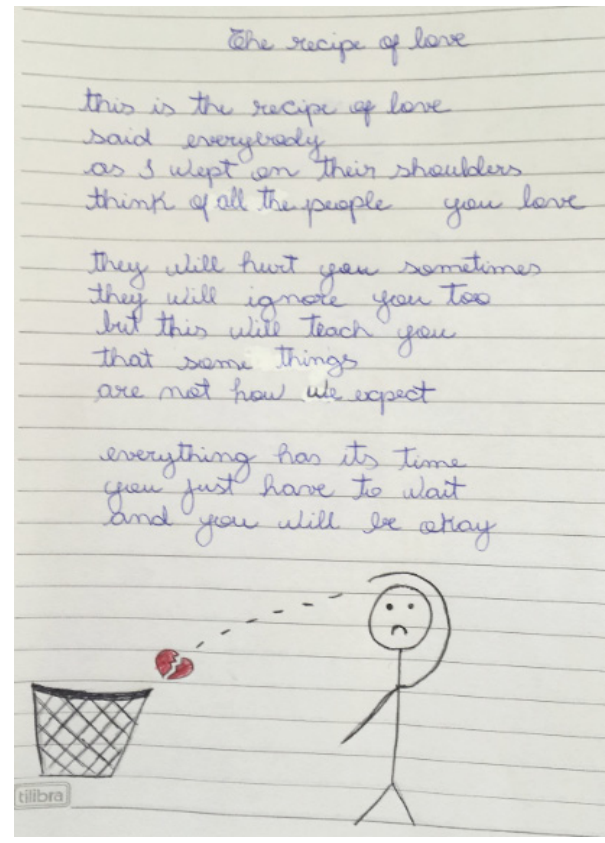

Figure 2. Ana and Bia's production 
It is important to emphasize that these students are 13 and 14-year-old eighth-graders, and during adolescence a theme, such as love is mainly shown in friendships and dating relationships (VIEJO, ORTEGA-RUIZ; SÁNCHEZ, 2015). Three pairs of students decided to write about love and friendship, probably because it is a common topic of conversation among them, and hence one they are familiar with.

In Figure 2, for instance, they used the same structure as that of Rupi Kaur's poem but changed certain words. They used 'love' and 'shoulder' instead of 'life' and 'arm'. Ana and Bia used the word "wept" which was presented to them in the pre-reading phase. The way they used it showed that they really understood its meaning. That is evidence of how the collaborative discussion held during the pre-reading phase helped them improve their vocabulary. In their paragraph, they mentioned that "we liked the experience of reading Rupi Kaur's poem because it was very interesting and we loved writing a new poem because we expressed everything that we were feeling".

Two pairs decided to write about the same topic, friendship, but their production shows that they have a different view of that topic:

[4] João and Pedro's production

This is the recipe of friendship

To be a good friend Just know how to listen

And knowing how to speak at the right time

To be friends is to support decisions

And help in diseases

The friend is the one you can

Count on for everything. 


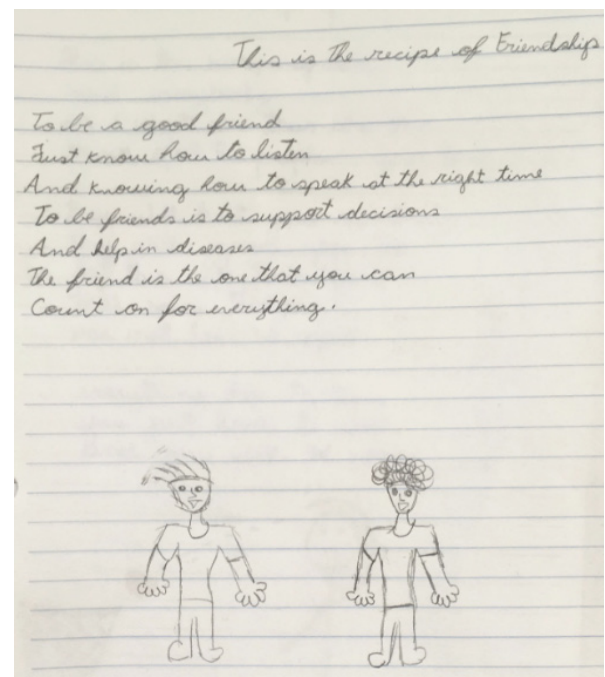

Figure 3. João and Pedro's production

\section{[5] Duda and Maria's production}

The friendship

Friendship is something very special

Because it is she who makes us better people

Friends are not for just good times

But also for bad times,

They become part of the people

and every moment together is as if we

were with a brother

Cherish your friend because today they are here beside you tomorrow we do not know. 


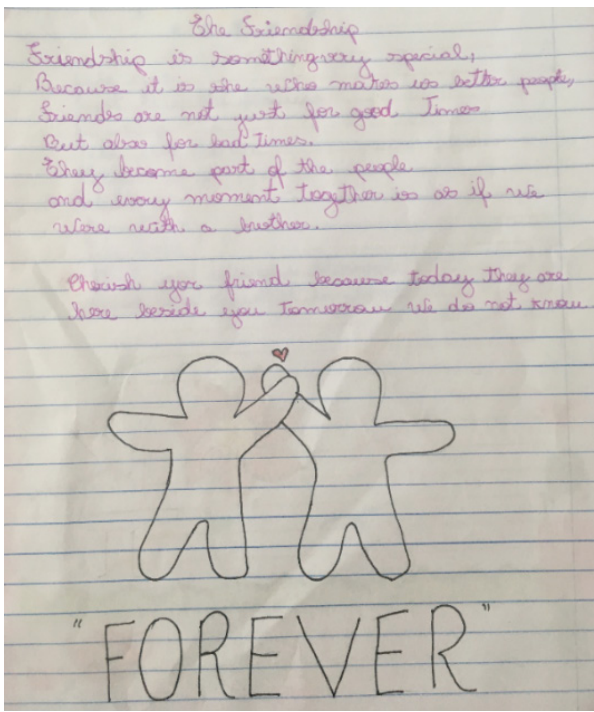

Figure 4. Duda and Maria's production

In Figure 3, João and Pedro tell us about what makes a good friend, things like listening and speaking at the right time, backing decisions and being there so your friend can be present in your life. It is worth highlighting here the students' perfect use of the expression "count on", which had not been studied formally at school. This might be evidence of the benefits of using a dictionary during an activity. Their illustration of the poem shows two boys, which might be themselves, the writers. In their paragraph, in the post-reading exercise, João and Pedro wrote that "our experience with Rupi Kaur and her poem was very good and inspiring. When we made our own poem we felt very happy with the feeling of doing something different but good at the same time".

In Figure 4, despite using the words "it is she who" instead of "it" in "because it is she who makes us better people", one can see their intention to personify friendship, presented in a positive way, as something which constitutes a person's identity. In the pre-reading activity during the debate, Duda mentioned that all these tragedies helped her figure out "that life changes easily". The idea of life's ephemerality is evident in the last stanza of their poem "today they are here beside you tomorrow we do not know". So that clearly shows how the pre-reading activity and the collaborative debate influenced their production.

The girls also used the word "cherish", a word not generally used in dayto-day conversations among students at this level of learning. My classroom experience has shown that they generally tend to use "take care of" instead of 
"cherish". This probably also shows the influence of dictionary use on their writing and their ability to choose a special new word to suit the particular writing genre they are producing, a poem. In their paragraph, they mentioned: "Rupi Kaur's poem was very interesting and inspirational. The opportunity to write a poem in pairs was very cool because we could discuss our opinions with our friend and express what we were feeling".

In Figure 5, students used rhyming couplets quite a lot in their poems:

[6] Ricardo and Paulo's production

To Timbuctu

Everybody one day will die But before

you need to eat a pie tell your parents all you wanna do

And get a plane to Timbuctu

While flying you see the

Sun

And you, I know, will have

fun

In Timbuctu you can your pie eat

To remove of the ground your feet 


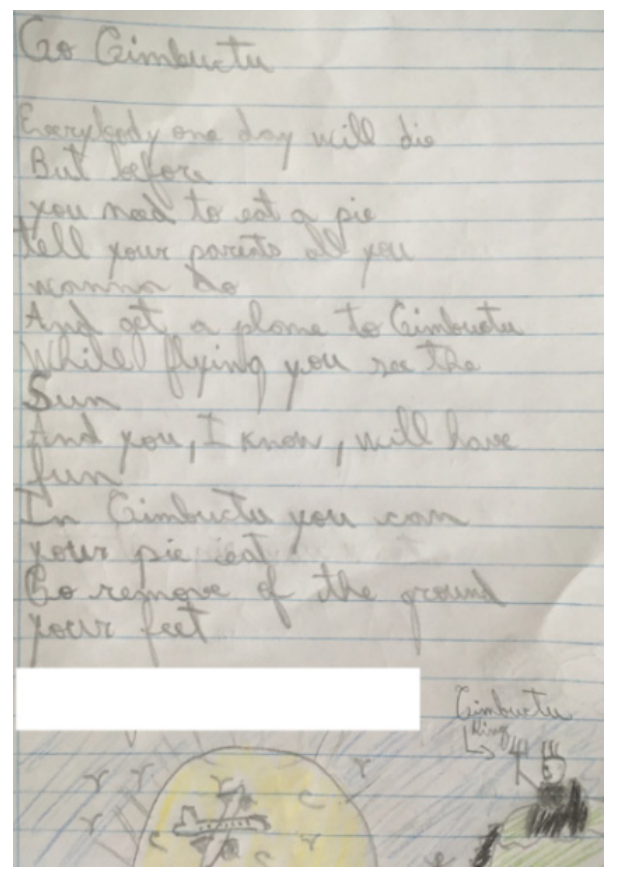

Figure 5. Ricardo and Paulo's production

As can be seen, the use of quite a lot of rhyming couplets, with endings such as die/pie, you/do/Timbuctu, sun/fun, eat/feet, show that Ricardo and Paulo believe that it was important to use rhyme to write a poem, so they made a lot of effort to use rhyme throughout. They based their poem on an imaginary place, Timbuctu, a nice place that everyone should know. The illustration of their poem truly represents the place and presents some new information about this imaginary place, as it has a king. The last line of the poem, "to remove of the ground your feet" could possibly refer to being in another dimension, forgetting, if only for a while, about all the problems that exist in the world, some of which were discussed in our pre-reading activity. Timbuctu, in this sense, represents not only a place of happiness, but also a place of freedom. In their paragraph, in the post-reading activity, Ricardo and Paulo mentioned that "Rupi's poem made us thought about if you fall and you be sad, you can feel relieved because everything will be better". And about writing a poem in pairs, they said "we liked it a lot because it was very cool to work together".

Duda and Lucas, in turn, preferred to write about the opposite of Rupi Kaur's poem: 
[7] Duda and Luca's production

the recipe of death

Once my father told me that the recipe for death is no need to cry No wilt

No one is going to help you

And to die all it takes

is to be alive.

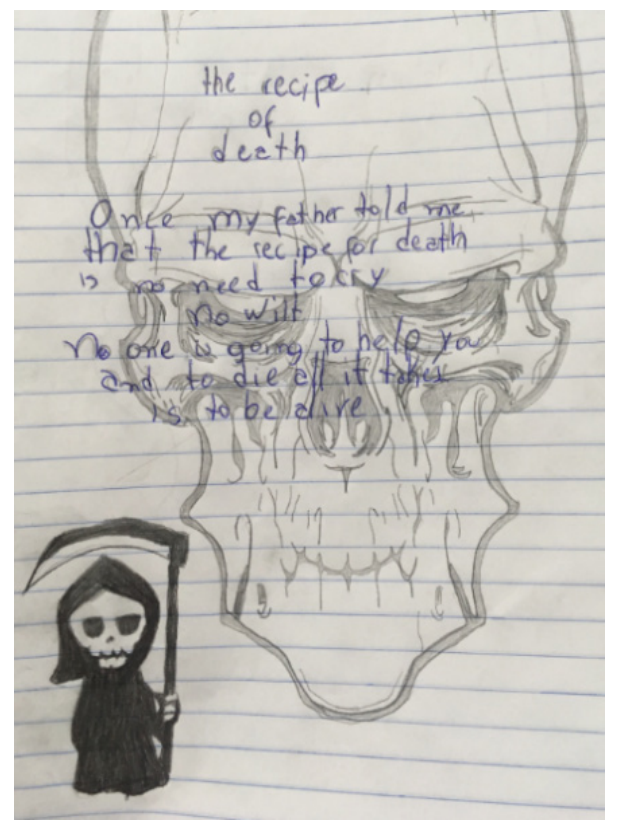

Figure 6. Duda and Lucas' production

In Figure 6, we see that the theme of this poem could have been influenced by the discussion in the pre-reading activity, in which many Brazilian tragedies, all on the theme "death" were presented.

In Rupi Kaur's poem, the poetic persona starts with a conversation with a mother. Duda and Lucas used the same structure as that of Rupi Kaur's poem but changed the poetic persona, showing their preference for a conversation with their father. In the fourth line, they used the word "wilt", a new word presented during the pre-reading activity. They also signaled life's ephemerality in the sixth and seventh lines when they mentioned that "to die all it takes is to be alive". During the post-reading activity, they wrote that "our experience of reading the 
poem and writing another one based on Rupi Kaur's poem was good because it was an experience of imagination. Our poem was the reverse form of the original poem. The original talks about life, our poem is about death".

Roberto asked to do this activity alone. As Figueiredo (2018) mentioned, teachers must respect students' different styles of learning and should not oblige them to work in groups, so Roberto was allowed to write the poem by himself. In the post-reading exercise, he stated: "I really enjoyed creating a poem but I preferred to make it by myself because I wanted to talk about some tips that I read on the book Os segredos da mente milionária". The idea of writing the poem by himself can be explained by his difficulty in trying to impose his idea on his classmate.

[8] Roberto's production

The secret of the millionaire mind

Money can not be spent without thinking it must be accumulated to provice freedom learn to control money if not it will control you if your motivation is negative as fear money never brings happiness to you this is one of the mind millionaire.

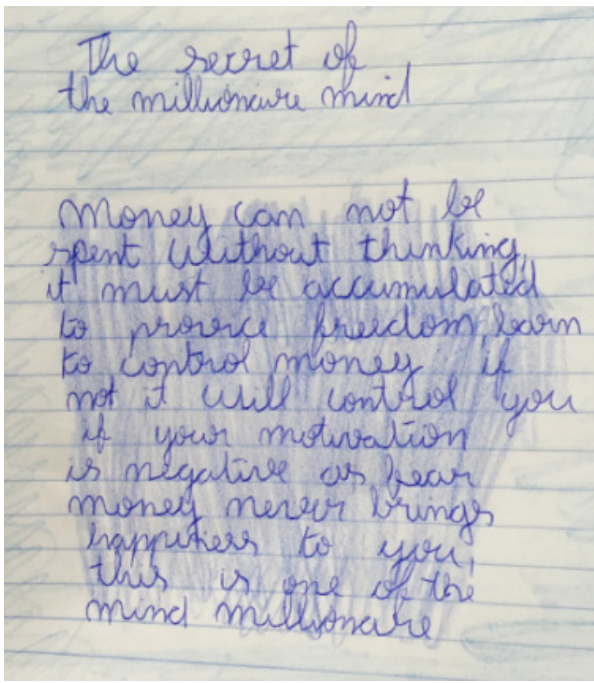

Figure 7. Roberto's production 
Roberto wanted to emphasize the importance of self-control in spending money and emphasized his critical point of view in relation to the theme, based on a book he had read earlier. Nowadays, because of the influence of capitalism, people tend to buy much more than they actually need and hope that such things will give them some kind of happiness. For Cole and Ferrarese (2018), capitalism is more than an economic system. They use the words of Marx to define it as a definite mode of life "that shapes our relationships with others, our sense of ourselves and our capacities, practices, and actions in the material world" (COLE; FERRARESE, 2018, p.105).

Daniel and Carol used a title similar to that used by Rupi Kaur but they resignified the whole poem by adding the dimension of how capitalism interferes in the lives of human beings:

[9] Daniel and Carol's production

Recipe of life

A man dies nobody cries

A woman dies nobody cries

A kid dies nobody cries

A baby dies

nobody cries,

The world keeps spinning.

A famous person dies

everybody cries,

The world stops.

Who's gonna cry for you? 

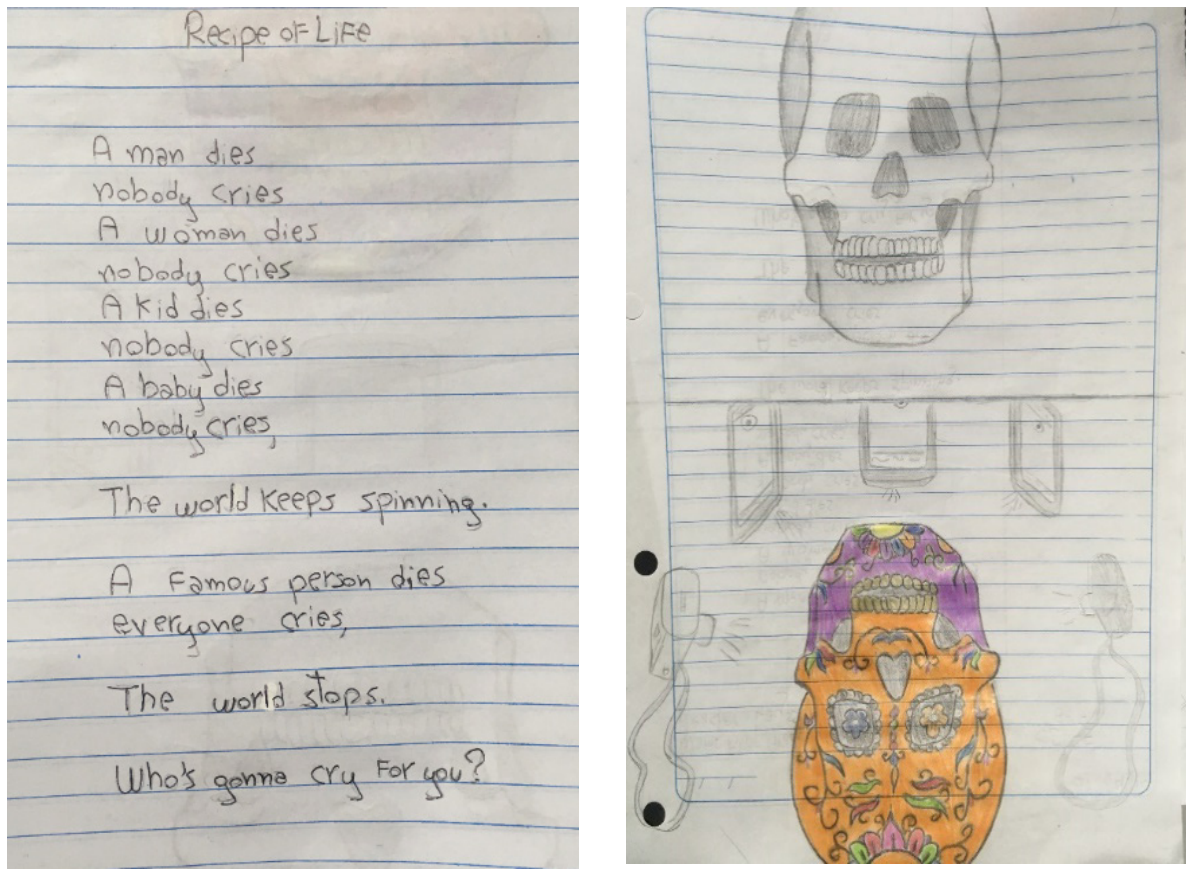

Figure 8. Daniel and Carol's production

Figure 8 shows that the students presented the life dilemmas caused by the influence of capitalism in a philosophical manner. They also used a rhyming couplet with endings cries/dies and a repetition of certain words to reinforce their idea that the poor suffer much more than the famous, in this sense, the rich. They ended their poem with a question which makes us think about who we really need to value in our lives. They draw a Mexican skull to illustrate their poem. This shows an influence or dialogue with another school subject and also their contact with the Spanish language and culture, which in this sense, contributed to enhancing their poem.

In Daniel and Carol's paragraph in the post-reading activity, they stated: "the poem was very nice and we really liked to write a poem in pairs because it was a nice opportunity. We could think about different things".

\section{FINAL COMMENTS}

The activities undertaken with eighth-grade students at a Brazilian public school showed that literary texts, in this specific study, a poem, can be used in an English language classroom at a public school. 
In general, students felt very motivated while doing all the exercises. In addition, the data showed an improvement in their vocabulary as a result of reading Rupi Kaur's poem and the collaborative practices. They used some of the words presented in the pre-reading exercise at different moments (discussions at whilereading and written production phases), showing that they really grasped the meaning of the task. They were able to reflect on certain current events in Brazil, such as the tragedies at the beginning of the year, and express their ideas in the creative poems they produced. In their paragraphs, written during the post-reading activity, the majority stressed that they enjoyed doing the activity in pairs, that they were able to express themselves through it and that Rupi Kaur's poem was inspirational for their lives.

One obstacle encountered in this study was the insecurity expressed by Isa during the writing activity, because at first, she believed she would not be able to write a poem in English. However, the support given by the researcher teacher in trying to show that she was not alone on that journey, that she would be assisted by her classmate, was fundamental in increasing her confidence as, in the end, she accepted to do the proposed activity.

This suggestion of an activity based on Rupi Kaur's poem is not intended to be the only way of working with this poem, as there are innumerous possibilities. It merely sets out to show foreign language teachers one way of promoting collaborative reading and writing based on a literary text.

\section{REFERENCES}

BRUMFIT, C. J.; CARTER, R. A. (1986). Literature and language teaching. Oxford University Press.

COLE, A.; FERRARESE, E. (2018). How capitalism forms our lives. Journal for Cultural Research, vol. 22, n. 2, pp. 105-112.

COLLIE, J.; SLATER, S. (1990). Literature in the language classroom: a resource book of ideas and activities. Cambridge University Press.

FIGUEREDO, C. J. (2006). A construção colaborativa do discurso em sala de aula de L2/LE: foco nas estratégias de comunicação. In: FIGUEIREDO, F. J. Q. de. A aprendizagem colaborativa de linguas: considerações conceituais e aplicações em distintos contextos. Goiânia: Editora UFG, 2018, 2ª ed., pp. 133-168. 
FIGUEIREDO, F. J. Q. de. (2006). A aprendizagem colaborativa de línguas: considerações conceituais e aplicações em distintos contextos. In: FIGUEIREDO, F. J. Q. de. (org.) A aprendizagem colaborativa de linguas. Goiânia: Editora UFG, 2018, 2a ed., pp.13-58.

FIGUEIREDO, F. J. Q. de. (1997). Aprendendo com os erros: uma perspectiva comunicativa de ensino de línguas. Goiânia: Editora UFG, 2015, $3^{\text {a }}$ ed. revista e ampliada.

FIGUEIREDO, F. J. Q. de. (2019). Vygotsky: a interação no ensino/aprendizagem de línguas. São Paulo: Parábola, 2019.

KAUR, R. (2015). Milk and Honey. Andrews McMeel, 2015.

KAUR, R. (2018). O que o sol faz com as flores. São Paulo: Planeta do Brasil, 2018.

KAUR, R. (2017a). Outros jeitos de usar a boca. São Paulo: Planeta do Brasil, 2017a.

KAUR, R. (2017b). The sun and her flowers. Andrews McMeel, 2017b.

LAGO, N. (2017). Understanding metaphorical texts in foreign literature. Humanities and Social Sciences Review, v.7, n.1, pp. 297-308.

LAGO, N. A. (2016). High education in Brazil: University students contact with English literature. Journal of Teaching and Education, v. 5, n. 1, pp. 659-670.

MASON, J. (1997). Qualitative researching. London: SAGE Publications, 1997.

REES, D. K.; PEREIRA, D. N.; MELLO, L. G. A. S. (2018). The use of children's literature in ELT in Brazil. Children's Literature in English Language Education Journal, volume 6, issue 1, pp. 45-62.

SABOTA, B. (2006). Traçando os fios da leitura em língua inglesa: por uma resolução colaborativa de exercícios de compreensão textual. In: FIGUEIREDO, F. J. Q. de. A aprendizagem colaborativa de línguas: considerações conceituais e aplicações em distintos contextos. In: FIGUEIREDO, F. J. Q. de. (org.) A aprendizagem colaborativa de linguas. Goiânia: Editora UFG, 2018, 2ª ed., pp. 99-132.

SHORT, M. H.i CANDLIN, C. N. (1986). Teaching study skills for English literature. In: BRUMFIT, C. J.; CARTER, R. A. Literature and language teaching. Oxford University Press, pp. $89-109$.

VALDES, J. M. (2001). Culture in literature. In: Culture bound: bridging the cultural gap in language teaching. Cambridge University Press, 2001. 
VIEJO, C.; ORTEGA-RUIZ, R.; SÁNCHEZ, V. (2015). Adolescent love and well-being: the role of dating relationships for psychological adjustment. Journal of Youth Studies, v.18, Issue 9.

VYGOTSKY, L. S. (1978). A formação social da mente, trad. José Cipolla Neto, Luís Silveira Menna Barreto e Solange Castro Afeche. São Paulo: Martins Fontes, 1998.

WANDERLEY, M. K. de S. (2017). De caos e âncoras: o poema na perspectiva do sujeitoleitor, entre a estética e o discurso. Revista Língua e Literatura, v.19, n.34, jul./dez., pp. 185-200.

WOBETO, R. (2012). Produção colaborativa de textos escritos em língua inglesa: um estudo de caso. Dissertação de Mestrado em Letras e Linguística, Faculdade de Letras, Universidade Federal de Goiás, Goiânia.

Recebido: 20/08/2019

Aceito: 21/09/2019

Publicado: 16/10/2019 